\title{
Doživljanje »begunske krize« skozi intervencijo v javni diskurz: mi kot Drugi v zgodovinski perspektivi slovenskega izseljenstva in integracijskih praks
}

\begin{abstract}
Ključne besede: »begunska kriza«, konstrukcija Drugega, moralna panika, migracije, integracijske prakse
\end{abstract}

DOI: $10.4312 /$ ars.10.2.79-92

\section{Uvod}

Pojem »begunska kriza« je skovanka, ki se je v javnem diskurzu pojavila poleti 2015. Pojavila se je v povezavi s slovenskim "nacionalnim» prostorom zaradi napovedi Madžarske 17. junija 2015, da bo na meji s Srbijo postavila 175 kilometrov dolgo ograjo ter tako zaustavila številne migrante in begunce, ki so vstopali na njeno ozemlje. Treba je poudariti, da se intenzivno ukvarjanje $\mathrm{z}$ »begunsko krizo« v Sloveniji ni pojavilo ob množičnih prihodih migrantov in beguncev na italijanske otoke $\mathrm{v}$ zadnjih petnajstih letih in prav tako ne pred napovedjo Madžarske o postavitvi ograje, ko so se množice beguncev in migrantov že mesece premikale po tako imenovani balkanski poti. Čeprav gre za sosednji državi, so bili tako italijanski otoki kot madžarsko-srbska meja dovolj oddaljeni, da javnega diskurza v Sloveniji nikoli ni preplavila resna skrb glede smiselnosti evropske in slovenske migracijske politike. ${ }^{1}$ Intenziven, kompleksen javni medijski, politični in strokovni diskurz se je na »begunsko krizo« osredotočil šele takrat, ko so množice migrantov prišle blizu slovenskemu »nacionalnemu« prostoru.

Najprej je alarmantni diskurz sprožilo predvidevanje, da se bo zaradi madžarske ograje smer njihove poti preusmerila proti Hrvaški in Sloveniji, potem pa ga je povzročalo dejansko množično prihajanje migrantov in beguncev na slovensko mejo od septembra 2015 dalje. Madžarska je mejo s Srbijo zaprla 20.

$1 \quad$ V zadnjih dvajsetih letih je neopazno potekal postopek zavračanja ljudi, ki so v Sloveniji prosili za status mednarodne zaščite. Podatki dokazujejo, da je bila stopnja pozitivno rešenih prošenj od leta 1995 do leta 2015 manj kot 2-odstotna, v zadnjih desetih letih 5,5-odstotna, v zadnjih petih letih pa 11-odstotna. Glej spletno stran Ministrstva za notranje zadeve: http://www.mnz.gov.si/si/mnz_za_ vas/tujci_v_sloveniji/statistika [1.7.2016]. 
septembra, prvi begunci in migranti so prišli na slovensko mejo 17. septembra 2015. Mesec dni pozneje, 17. oktobra, je Madžarska zaprla tudi mejo s Hrvaško in tako imenovana balkanska pot je bila $\mathrm{v}$ Avstrijo in Nemčijo dokončno preusmerjena preko Slovenije. V tem času se začne javni diskurz oblikovati kot izraz moralne panike, ki kulminira $\mathrm{v}$ naslednjih mesecih: najprej ob velikem številu ljudi, ki prečkajo Slovenijo, potem ob postavljanju ograje na meji s Hrvaško od 11. novembra dalje, nazadnje pa ob napovedih Avstrije februarja 2016, da bo zmanjšala dnevni sprejem migrantov iz Slovenije. Z zaprtjem balkanske poti 18 . marca 2016 se je intenzivno in alarmantno javno obravnavanje »begunske krize» tako nenadno, kot se je začelo, tudi končalo. ${ }^{2}$

Prispevek bo prikazal osnovno temo intervencije, ki sem jo kot raziskovalka izbrala v svojih številnih javnih nastopih in medijih. Od začetka krize jeseni 2015 do zaprtja balkanske poti spomladi 2016, ko je bila potreba po pojasnjevanju potekajočih dogodkov velika, smo bili $\mathrm{k}$ pojasnjevanju $\mathrm{v}$ javnosti in medijih povabljeni tudi poznavalci in poznavalke migracij. To je bila velika novost, saj smo sodelavci Inštituta za slovensko izseljenstvo in migracije ZRC SAZU v marginalnem položaju, tako kot je v javnem prostoru marginalizirana tema migracij, ki je večje pozornosti deležna le ob medijsko razvpitih in "alarmantnih « dogodkih. ${ }^{3}$ Številni poznavalci $z$ Inštituta za slovensko izseljenstvo in migracije ZRC SAZU, Mirovnega inštituta ter drugih raziskovalnih in strokovnih institucij so intenzivno sodelovali $\mathrm{v}$ javnih razpravah. Osebno sem sodelovala ali pisno prispevala svoje mnenje na štiriindvajsetih dogodkih oziroma medijskih straneh in oddajah. V svojih javnih intervencijah sem dosledno in brez izjeme naslavljala dva sklopa strahov, ki sta prevladovala $\mathrm{v}$ javnem diskurzu: tistega o valovih in nepreglednih množicah ljudi, ki grozijo, da bodo preplavili našo deželo in kontinent, ter tistega o množicah Drugih, drugačnih in čudnih, ki jih ne bo mogoče integrirati na ravni Evrope in Slovenije. Za tak način oziroma zavračanje teh dveh sklopov predpostavk sem se odločila zato, da bi vztrajnemu ponavljanju sumničenj in obtožb glede beguncev in migrantov v kontekstu ogroženosti naroda in države zoperstavila prav tako ponavljajoče se informacije o lastnih izkušnjah migrantstva in begunstva slovenskega in evropskega prostora. Vsaka intervencija je vsebovala podatke o (slovenskem) izseljenstvu in begunstvu, izkušnji, ki je potlačena in izrinjena iz kolektivnega spomina, nacionalne zgodovine, kulture in šolskega sistema, ter podatke o integraciji migrantov in beguncev, ki na ravni Slovenije poteka zadnjih petindvajset let (v sklopu skupne države Jugoslavije vsaj od začetka 70. let 20. stoletja), na ravni Evropske unije pa zadnjega pol stoletja. Tudi potlačevanje teh izkušenj in ignoriranje teh dejstev je javnemu diskurzu jeseni leta 2015 omogočilo

2 Za analizo medijskega in javnega diskurza v Sloveniji od začetka »begunske krize« do konca leta 2015 gl. Bajt (2016) in Pajnik (2016).

3 Tak primer je izjava Angele Merkel iz leta 2010, da je multikulturalizem v Nemčiji mrtev. 
vpeljavo alarmantnega pojma »begunska kriza«, ki sem se mu poskusila zoperstaviti $s$ poudarjanjem slovenskih in evropskih migracijskih zgodovinskih dejstev in integracijskih praks.

\section{Moralna panika in konstrukcija Drugega}

Pri odločitvi za opisani način intervencije sem izhajala iz ugotovitve, da se lahko alarmantni diskurz o migracijah $\mathrm{v}$ javnem prostoru nezaustavljivo širi zaradi slabega poznavanja in razumevanja migracij tako v slovenskem kot evropskem prostoru. Za nepoznavanje so trije razlogi. Prvi je dejstvo, da se o migracijah v šolskem sistemu na vseh stopnjah ničesar ne naučimo, ker niso vključene v kurikule; drugi je dejstvo, da migracije ne ustrezajo prevladujoči metanaraciji nacionalne zgodovine in kulture, ki temelji na mitološki čistosti naroda in homogenosti kulture; tretji pa izhaja iz opisane reakcije na aktualne probleme migracijske politike, ko se samo ob najbolj drastičnih primerih prihoda migrantov in beguncev na nacionalne meje sproži javni diskurz, ki postavi strogo ločnico med nas, ki smo »od tu od vedno«, in njih, ki so množični vsiljivci ter poosebljajo grozečo nevarnost.

Ahistorična interpretacija migracij temelji na konstruktu razločevanja med nami, »normalnimi«, ki naj bi bili večno sedentarni in ukoreninjeni, ter drugimi, ki se premikajo, so izkoreninjeni, mobilni in nezaustavljivi ter predstavljajo odstopanje od normalnosti in torej že po definiciji ustrezajo profilu Drugega, drugačnega, nenormalnega. S konstrukcijo Drugega je odprta pot javni imaginaciji, ki lahko vanj projicira vse, kar je potrebno, da je lahko dehumaniziran in uporabljen za javni diskurz ogroženosti, nevarnosti in moralne panike. Termin moralna panika uporabljam v pomenu, ki ga je definiral Stanley Cohen:

stanje, epizoda, oseba ali skupina oseb, definirana kot grožnja socialnim vrednotam in interesom; množični mediji njihove značilnosti predstavljajo na stiliziran in stereotipen način; moralne barikade upravljajo uredniki, škofi, politiki in drugi desno razmišljujoči ljudje; družbeno akreditirani strokovnjaki ponujajo diagnoze in rešitve; pojavijo se načini reševanja oziroma se (pogosteje) zatekajo k njim; stanje potem izgine, ponikne ali razpade in postane vidnejše (Cohen 2011, 1).

Avtor je v uvodu k tretji izdaji knjige (koncept moralne panike je utemeljil že leta 1972) med sedem sodobnih predmetov moralne panike uvrstil tudi begunce in iskalce azila, ki so v splošno razpravo o priseljevanju v Veliki Britaniji in vsej Evropi vključeni že od devetdesetih let prejšnjega stoletja. To še toliko bolj velja za Slovenijo, in sicer zaradi nastanka in formiranja nacionalne države $\mathrm{v}$ izrazito nacionalističnem političnem in javnem diskurzu. Moralne panike so namreč, kot $\mathrm{v}$ omenjenem 
uvodu pravi Cohen, »kondenzirani politični boji za nadzor nad sredstvi kulturne reprodukcije« (prav tam, xIiv).

Moralna panika je v Sloveniji bolj ali manj izrazita skozi celotno obdobje samostojne države od 1991 dalje: najprej so bili njen predmet begunci iz jugoslovanskih vojn, pozneje »Neslovenci«, »izbrisani« in iskalci azila. Vendar ni to nič izjemnega. Za evropski prostor je Homi Bhabha že leta 1993 preroško napovedal razvoj strahu in panike pred migranti. $\mathrm{V}$ obdobju optimističnih napovedi razvoja evropskega prostora kot prostora sodelovanja, odprtosti in tolerantnosti je zagovarjal drugačno razumevanje prihodnosti:

Ne dvomim, da bo rasizem postal - da že postaja - hujši pod vplivom thatcherizma, sodobnega konservativnega etosa, pa tudi evropske trdnjave, ki bo okrepila svoje meje in celo, kot vidite $\mathrm{v}$ Nemčiji in delih Italije, sprožila izjemno paranojo pred tistimi, ki so zunaj trdnjave, pred tistimi, ki so »plenilci«, iskalci dela, tatovi delovnih mest iz tretjega sveta, begunci, ki se hočejo izmuzniti skozi meje. Smo v zelo problematičnem položaju s popolnoma novim diskurzom paranoje, ki se pojavlja na obrobju Evrope prav v času, ko nas hočejo prepričati, da bodo znotraj Evrope propustne meje, nova prijaznost in novo tovarištvo (Bhabha, 1993, 194).

Migranti in begunci so lahek plen kreatorjev rasizma in moralnih panik tudi zaradi omenjenega nepoznavanja migracij v zgodovini nacionalnega in evropskega prostora ter njihove odločilne vloge pri kreiranju sestave prebivalstva znotraj držav in naddržavnih entitet. Odsotnost teme migracij v nacionalnem šolskem in kulturnem sistemu lahko razumemo v funkciji konstrukcije nacionalne identitete, kot jo razlaga Anthony D. Smith. Najpomembnejša funkcija nacionalne identitete je po Smithu socializacija članov v državljane in pripadnike naroda, ki jo izvaja obvezni, standardizirani, množični šolski sistem, preko katerega državna oblast upa, da bo nacionalno predanost in posebno, homogeno kulturo privzgojila $\mathrm{z}$ dejavnostjo, ki jo pod vplivom nacionalističnih idealov kulturne avtentičnosti in enotnosti večina režimov izvaja z veliko energije (Smith, 1991, 16).

Druga funkcija je ustvarjanje družbene vezi med posamezniki preko kreiranja skupnih vrednot, simbolov in navad, ki sestavljajo skupno nacionalno dediščino. Tretja funkcija nacionalne identitete pa je način, kako posamezniki najdejo odgovor na vprašanje, kdo sem. Ta način vzpostavlja razmerje med nacionalnim in nenacionalnim delom posameznikove identitete, kar je najpogostejši element človekove identitete, zlorabljen za politične cilje nacionalnih projektov (prav tam, 17). Iz tega opisa je jasno, zakaj $\mathrm{v}$ procese formiranja nacionalne identitete od 19. stoletja dalje ni mogoče umestiti koncepta migracij, mobilnosti in mešanosti, ampak zgolj koncept 
»čistosti« - kulture, identifikacije, lojalnosti, identitete, dediščine in jezika. V okviru znanstvenega razumevanja sveta, ki se je v 19. in 20. stoletju spojilo z nacionalnimi in nacionalističnimi koncepti državnosti in državljanstva, je prevladal model »čistosti« kot absolutno načelo organiziranja družbe in države, ki še vedno ni presežen. Še več, še vedno ga ogroža poznavanje in razumevanje zgodovinskih dejstev migracijskih tokov, ki že stoletja povzročajo mešanje ljudi, kulturne in jezikovne stike ter hibridiziranje identitet (Sedmak, 2011; Štih, 2010).

\section{Slovensko izseljenstvo, begunstvo in prebežništvo}

$\mathrm{V}$ svojih intervencijah $\mathrm{v}$ javni prostor sem se interpretiranja in analiziranja »begunske krize« vedno lotila $\mathrm{z}$ opozarjanjem na izkušnje migrantstva in begunstva $\mathrm{v}$ slovenskem in evropskem prostoru. Na javnost sem se obrnila s predlogom, naj se vsak spomni subjektivnih, osebnih, intimnih, družinskih, sorodstvenih, krajevnih, lokalnih in nacionalnih zgodb o migracijah $\mathrm{v}$ slovenskem in evropskem prostoru. Poleg premisleka o migrantskih zgodbah pa nam že same številke in geografski diagrami migracijskih smeri v novejši zgodovini najbolj nazorno pokažejo, kako množični in dolgotrajni so bili valovi in pritoki slovenskih in evropskih izseljevanj, begunstva in prebežništva, ki so »butali« ob obale in »preplavljali« države na drugih celinah, pa tudi znotraj evropskega kontinenta. Iz Evrope se je po grobih ocenah v obdobju od sredine 19. do sredine 20. stoletja v Severno in Južno Ameriko, Avstralijo in Afriko izselilo 55 milijonov ljudi. Razlogi so bili osebni, družinski, predvsem pa politični in ekonomski. V Evropi so vladali revščina, lakota in brezizhodnost, verska ter ideološka nestrpnost in pogromi, razmere pa so še zaostrovale dolgoletne vojne ter posledice revolucij in povojnih maščevalnih obračunavanj. V začetku 20. stoletja, ko je imelo slovensko etnično ozemlje 1.200.000 prebivalcev, se je samo v Združene države Amerike izselilo okoli 200.000 ljudi. V popisu prebivalstva leta 1910 je za svoj materni jezik slovenščino izbralo 183.000 priseljencev v ZDA (Drnovšek, 1999, 13). V prvem desetletju 20. stoletja je bilo priseljevanje v ZDA največje prav iz avstro-ogrskega cesarstva. Slovenci so bili del množičnega izseljevanja iz osrednje in vzhodne Evrope, ki je predstavljalo »največjo in najnovejšo skupino priseljencev na prelomu stoletja« (Gabaccia, 2002, 142). Privlačni smeri slovenskega izseljevanja sta bili tudi Argentina in za krajše obdobje Brazilija (Kalc, 2002).

Med prvo svetovno vojno je bila iz zahodnega dela slovenskega naselitvenega prostora izseljena večina prebivalstva. Begunstvo je v Evropi dobilo, kot navaja Petra Svoljšak, biblične razsežnosti. Iz vojnih območij na zahodni in vzhodni fronti so bile pregnane oziroma poslane v begunstvo desetine milijonov ljudi. Soška fronta je povzročila begunstvo prebivalstva $\mathrm{v}$ notranjost avstro-ogrskega cesarstva in Italije. 
Avtorica navaja, da je bilo med vojno v notranjost avstrijske monarhije pregnanih okoli pol milijona beguncev, od tega 65.000 slovenskih beguncev iz avstrijskega primorja, v notranjost Italije pa okoli 12.000 slovenskih beguncev (Svoljšak, 2016, 15). Približno 15.000 slovenskih medvojnih beguncev se ni hotelo vrniti na svoje domove, ki so zaradi novozačrtanih meja razpadlega cesarstva po vojni ozemeljsko pripadli Italiji. Zaradi ruske revolucije, razpada večnacionalnih imperijev in nastanka novih nacionalnih držav, v katerih naj bi živeli mitološko "čisti« narodi, je begunstvu med vojno sledilo množično begunstvo več kot 10 milijonov ljudi po njenem koncu, ki so ostajali razseljeni še deset let po končani vojni (prav tam, 17).

Po prvi svetovni vojni in množičnem begunstvu prebivalstva se je nadaljevalo slovensko izseljevanje v Argentino. Nadaljevale so se tudi množične migracije žensk iz goriških vasi v egiptovska mesta, ki so se začele ob koncu 19. stoletja. Po približnih ocenah naj bi v začetku 20. stoletja v Egiptu živelo okrog 5000 slovenskih deklet in žensk, ki so opravljale različna dobro plačana gospodinjska in skrbstvena dela. Odhajale so tudi slamnikarice, pletilke slamnikov, iz območja Domžal in Mengša (Drnovšek, 2003). Med svetovnima vojnama so moški odhajali delat v belgijske, francoske in nemške rudnike in tovarne. Posebej močno je bilo izseljevanje iz Primorske po priključitvi tega dela ozemlja Italiji leta 1918. Ocenjuje se, da je zaradi fašistične politike iz Julijske krajine prebegnilo ali se izselilo okoli 100.000 Slovencev in Hrvatov (Kalc, 2002, 41). Mnogi so ilegalno prestopili takratno mejo med Italijo in Jugoslavijo.

$\mathrm{V}$ času druge svetovne vojne je bilo po ocenah Damirja Josipoviča z ozemlja današnje Slovenije (prisilno) deportiranih okrog 100.000 ljudi. V to številko vključuje tudi »slovenske Jude in slovensko nemško govorečo skupnost (skupaj 15.000)«(Josipovič, 2015, 147-148). Leta 1945 je zaradi političnih nazorov čez mejo v Avstrijo prebegnilo 17.000 Slovencev, ki so dobili mednarodni status razseljenih oseb, »displaced persons«. Po večletnem bivanju v avstrijskih begunskih taboriščih so jim zatočišče ponudile predvsem Argentina, Združene države Amerike, Kanada in Avstralija (Vodopivec, 2006, 309-311).

Množično razseljevanje se je po letu 1945 nadaljevalo v vsej Evropi, saj so bili, podobno kot po koncu prve svetovne vojne, milijoni beguncev brez domov ali držav še desetletje po koncu druge svetovne vojne. Zaradi izgonov prebivalstva, deportiranih ljudi, ki se niso imeli kam vrniti, preganjanja, množičnih preselitev in bega pred maščevalnimi poboji je bilo preseljevanje tako množično, da velja desetletje po letu 1945 za največje migracijsko gibanje prebivalstva v zgodovini evropskega kontinenta. V Sloveniji se je razseljevanje, izseljevanje in prebežništvo dogajalo med drugim na Goriškem in v Posočju ter ob Obali. Nevenka Troha navaja, da so ohranjeni delni podatki za okraj Gorica, »iz katerega je v letu 1947 pobegnilo oziroma se odselilo 
1814 ljudi, nato pa do sredine leta 1951 še 880 «(Troha, 2000, 264). Do januarja 1947 se je za preselitev prijavilo 25 odstotkov družin na Breginjskem, v Brdih je bilo več kot 300 izselitev, iz župnije Gornje Polje se je izselilo »10 družin domačinov, nekaj iz Ročinja in Volč, veliko tudi iz hribovskih vasi na Kambreškem « (Troha, 2010, 435). Iz obalnih mest in njihovega zaledja se je v desetih letih po koncu druge svetovne vojne izselilo več kot 90 odstotkov italijanskega prebivalstva. Nevenka Troha ocenjuje, da se je od leta 1945 do leta 1958 iz koprskega okraja izselilo 25.062 oseb (Troha, 2000, 261).

V obdobju od leta 1955 do konca sedemdesetih let so se evropski migranti z juga in jugovzhoda Evrope množično selili v severno Evropo: v Nemčijo, Francijo, Belgijo in na Švedsko. Nemčija je prvi sporazum o "gastarbeiterjih«, gostujočih delavcih danes bi rekli ekonomskih migrantih -, sklenila z Italijo leta 1955. Sledili so sporazumi s Španijo, Grčijo, Turčijo, Portugalsko in leta 1968 z Jugoslavijo, katere del je bila do leta 1991 tudi Slovenija. Iz Slovenije so se po letu 1968 v Nemčijo izseljevali tisoči delavcev in njihovih družin ter postali del milijonskega preseljevanja prebivalstva iz južnih in jugovzhodnih delov na sever Evrope. V zadnjih letih se Slovenci ponovno izseljujejo. V nobenem letu po osamosvojitvi se iz Slovenije ni izselilo toliko mladih slovenskih državljanov, starih od 15 do 29 let, kot leta 2012, ko jih je odšlo 1570 - največ v Nemčijo, Avstrijo in na Hrvaško. Anton Gosar je leta 1978 ocenil, da v Združenih državah Amerike živi približno 400.000 slovenskih izseljencev oziroma njihovih potomcev, v Kanadi pa približno 40.000. V Južni Ameriki živi največ Slovencev in njihovih potomcev v Argentini, in sicer okrog 30.000, v Avstraliji pa okrog 20.000. Okrog leta 1980 je v Nemčiji živelo približno 60.000 Slovencev, v Avstriji okoli 35.000, v Franciji in Beneluksu okrog 20.000, v Veliki Britaniji 7000 ter na Švedskem okrog 6000 (Gosar, 1978). Močno izseljevanje je zadnjih sto let potekalo tudi v jugoslovanskem prostoru, kjer se je po popisu prebivalstva leta 1991 za slovensko narodno pripadnost opredelilo 34.464 ljudi (Josipovič, 2014, 124).

\section{Primeri dobrih praks integracije otrok migrantov v Sloveniji}

$\mathrm{V}$ času »begunske krize« je za razvoj strahu in panike pred migranti prevladujoč javni diskurz uporabljal metafore vode: valov, poplav, pritokov in tokov; kriminala: teroristi, goljufi, lažnivci; ter grozeče nevarnosti: nezaustavljive množice, bolezni in epidemije. Prihajajoči migranti in begunci so bili interpretirani kot naravna katastrofa in varnostna grožnja. Zato je bilo tudi vprašanje njihove (potencialne) integracije $\mathrm{v}$ slovensko in evropsko družbo zastavljeno $\mathrm{v}$ kontekstu naraščajoče nestrpnosti, poudarjenega sovražnega govora in prevladujočega varnostnega diskurza. V svojih 
intervencijah v javni prostor sem vprašanje, kako bo mogoče »tolikšno« število migrantov integrirati v slovenski in evropski prostor, naslavljala $\mathrm{z}$ zgodovinskimi in sodobnimi primeri integracijskih praks. Izhajala sem iz zgoraj navedenih podatkov o migracijah kot ključnem dejavniku mešanja ljudi ter premisleka, ki ga definiram kot zrcalno razumevanje migrantstva. Gre za to, da slovensko izseljenstvo in priseljenstvo v Slovenijo proučujemo $\mathrm{z}$ enakimi metodološkimi in konceptualnimi pristopi: tako imenovani "naši « izseljenci so tudi priseljenci nekam drugam in priseljenci v Slovenijo so izseljenci od nekod drugod. Za vse pa veljajo enaki motivi migriranja - ustvariti bolj kakovostno ali varnejše življenje zase in za svoje otroke - in enaka pot do cilja: socialna vključenost oziroma integracija. Primeri integracije slovenskih izseljencev v naselitvenih okoljih so številni in ne izključujejo sočasnega ohranjanja kulturne identitete na vseh celinah sveta, od Združenih držav Amerike do Švedske (Lukšič Hacin, 2001; Milharčič Hladnik, 2004; Repič, 2006; Vižintin, 2016).

Kljub prevladujočemu prepričanju, ki ga je dogajanje v času »begunske krize» še utrdilo, namreč da živimo $\mathrm{v}$ prostoru $\mathrm{z}$ naraščajočim rasizmom in odporom do migrantov, raziskave prikazujejo kompleksnejšo sliko. Ocenjuje se, da v Evropski uniji živi 12 milijonov tako imenovanih evropskih muslimanov, ki so se priselili v času razpadanja francoskega in britanskega kolonialnega imperija, v obdobju bilateralnih sporazumov o "gostujočih delavcih« in v zadnjih nekaj desetletjih, ko so se evropske države iz držav izseljevanja spremenile v države priseljevanja. Skupaj z množicami ekonomskih migrantov iz držav južne in jugovzhodne Evrope v države severne Evrope od šestdesetih let 20. stoletja dalje ter migrantov iz drugih delov sveta so ustvarili kulturno, jezikovno, versko in etnično mešana prebivalstva in okolja. Težko si je predstavljati, da se v zadnjih petdesetih letih v Veliki Britaniji, Franciji, Nemčiji, Avstriji, Švedski, Belgiji, Italiji in drugje ne bi razvile na vseh področjih uspešne integracijske prakse, ki so omogočile, da evropske družbe ostajajo ekonomsko in socialno varne in ugodne za življenje ter da pripadajo gospodarsko razvitemu in bogatemu delu sveta.

Integracija oziroma vključevanje priseljencev je po letu 1960, v obdobju »gostujočih delavcev«, pomenila predvsem vključevanje v trg dela in, selektivno, v sistem države blaginje. Ko je postalo jasno, da se "gostujoči delavci« ne bodo vrnili domov, temveč so se jim pridružile družine, so integracijske politike začele vključevati vsa področja vsakdanjega življenja, predvsem kulturno, politično in izobraževalno. Romana Bešter integracijo opiše kot dvo- ali večsmeren proces obojestranskega prilagajanja priseljencev in večinske družbe:

$\mathrm{V}$ procesu integracije priseljenci postanejo aktivni in enakopravni udeleženci socialnih, ekonomskih, pravnih, političnih in kulturnih odnosov in procesov $\mathrm{v}$ državi sprejemnici, pri čemer je vsakemu zagotovljena možnost izražanja in ohranjanja njegove lastne kulture, vere in etnične pripadnosti. Integracijski 
model temelji na medkulturnem (interkulturnem) pristopu, ki dopušča ohranjanje različnih kulturnih in etničnih identitet, vendar posameznikov ne obravnava primarno kot člane etničnih ali kulturnih skupin. Poudarek je na kulturni raznolikosti družbe kot celote in večplastnosti kulturnih identitet posameznikov, ki sestavljajo družbo in posamezne etnične skupine (Bešter, 2007, 118).

Različne raziskave so pokazale, da tudi v Sloveniji obstaja mreža institucij, organizacij in posameznikov, ki delujejo na različnih področjih integracije priseljencev. ${ }^{4}$ Po vsej Sloveniji delujejo ljudje, ki se kot učitelji, mladi aktivisti, člani nevladnih organizacij, zaposleni v knjižnicah in na ljudskih univerzah, študenti prostovoljci in strokovnjaki trudijo na različnih področjih integracije. Premislek akterjev, ki na ta način delujejo v lokalnih okoljih, izhaja iz prepričanja, da je sožitje raznolikih kultur možno kot nova kakovost medčloveških odnosov. Lahko bi trdili, da skupine ljudi in posamezniki delujejo $\mathrm{v}$ smeri integracijskih praks ter prehitevajo institucije in njihov ekskluzivizem, ki ga velikokrat spodbujata dnevna politika in njena medijska pokritost. Med številnimi primeri naj omenim primere dobrih praks integracije otrok migrantov in njihovih staršev, ki so jih razvili na osnovni šoli Koper, na osnovni šoli Matije Čopa in Jakoba Aljaža v Kranju, na osnovnih šolah v Idriji, Slovenj Gradcu, Mariboru, na osnovni šoli Livada v Ljubljani ter na I. gimnaziji Maribor. Integracijske prakse v lokalnem okolju že desetletja izvajajo v Društvu za razvijanje prostovoljnega dela Novo mesto, Družinskem in mladinskem centru Cerklje, na Ljudski univerzi v Kopru in v številnih knjižnicah po Sloveniji, na primer v knjižnicah Kranj, Izola, Piran ter v knjižnici Kamnik, kjer so pred kratkim odprli oddelek $s$ knjigami v jezikih prebivalcev kamniške občine, katerih prvi jezik ni slovenščina. Pri takšnih praksah gre za bistvo integracije, kjer je poudarjena, kot pravi Natalija Vrečer, »dvosmernost procesa, saj integracija pomeni, da se ne prilagajajo državi sprejema samo priseljenci, temveč da so tudi nosilci kultur znotraj države sprejema pripravljeni sprejeti na novo prispele priseljence in se od njih učiti« (Vrečer, 2007, 35). Najbolj znan primer dobre integracijske prakse je iz Socialnega centra Rog v Ljubljani, kjer se dogajajo intenzivna srečevanja in medsebojno učenje migrantov, beguncev in iskalcev azila, tako odraslih kot otrok in družin, ter pripadnikov družbe sprejema. ${ }^{5}$ Člani različnih družbenih gibanj ter različnih skupin migrantov in beguncev so v prostorih Roga razvili ne le integracijsko prakso kot dvosmeren proces, temveč ob njej tudi identiteto upora. Integracijsko prakso želijo preseči z opozarjanjem na to, da je integracija premalo,

4 Med njimi sta raziskava Strokovne podlage, strategije in teoretske tematizacije za izobraževanje za medkulturne odnose ter aktivno državljanstvo (www.medkulturni-odnosi.si) in projekt Izboljšanje usposobljenosti strokovnih delavcev za uspešnejše vključevanje učencev in dijakov priseljencev $v$ vzgojo in izobraževanje (http://www.medkulturnost.si/dobre-prakse/).

5 Njihova spletna stran z najavami dogodkov: http://www.njetwork.org/Socialni-center-Rog [15. 11. 2016]. 
saj lahko zavaja in zakriva splošno socialno izkoriščanje in sistemsko diskriminacijo migrantov in beguncev v slovenskem in evropskem prostoru.

\section{Zaključek}

Sodobne družbe in njenih fenomenov - vključno s sodobnimi migracijami in »krizo beguncev« - ne moremo razumeti brez poznavanja zgodovine migracij, ki pa se jih zaradi »metodološkega nacionalizma« največkrat niti ne zavedamo. To je znanstveno proizvedena in reproducirana predpostavka, po kateri je narod-državadružba »naravna " politična in družbena forma sodobnega sveta; da je nacionalna država (zaprta) posoda družbenih procesov - kulture, umetnosti, znanosti, razvoja tehnike in tehnologije; ter da so ti teritorialno zamejeni znotraj ahistoričnega prostora nacionalne države s homogenim narodom in enotnim jezikom (Wimmer, Glick Schiller, 2002). S takšnim vseobsegajočim spontanim, a dejansko privzgojenim in naučenim mišljenjem lahko prekinemo tako, da delegitimiziramo, kar je razumljeno kot samoumevno, dekonstruiramo, kar se kaže kot neuničljivo, in denaturaliziramo, kar je videti kot večno, kot pravi Abdelmalek Sayad. Avtor opozarja, da so prav migracije »subverzivni faktor, ker razkrijejo skrito resnico in najgloblji temelj socialnega in političnega reda nacionalne države (Sayad, 2004, 281). Skrita resnica in najgloblji temelj nacionalnih držav so njihova etnično nehomogena, kulturno divergentna, jezikovno pestra in versko raznovrstna prebivalstva, ki so nastala skozi dolgo zgodovino migracij in mobilnosti ljudi in - kar je ključno - na ta način še vedno nastajajo. Prav zaradi subverzivnosti izbrane teme so bile opisane intervencije $\mathrm{v}$ javni prostor toliko bolj učinkovite. Načrtno ignoriranje govora o »begunski krizi« in vztrajanje pri ozaveščanju o evropski in slovenski zgodovini izseljevanja, prebežništva in begunstva kot osnove za vsako razpravo o »begunski krizi« je vsakokrat povzročilo začudenje in čudenje. Intenzivno izseljevanje in begunstvo iz evropskega in slovenskega prostora, včasih celo »bibličnih razsežnosti«, temelji na zgodovinskih dejstvih in številkah, ki sprožajo procese spominjanja na osebne, družinske, sorodstvene in hkrati širše migracijske zgodbe. Spominjanje in razmislek pa sta prvi korak k dojemanju »begunske krize« izven diskurza ogroženosti in moralne panike, $\mathrm{v}$ širšem zgodovinskem kontekstu formativnih procesov sodobne evropske in slovenske družbe.

\section{Literatura}

Bajt, V., Anti-Immigration Hate Speech in Slovenia, v: Razor-Wired. Reflections on Migrant Movements through Slovenia in 2015 (ur. Kogovšek Šalamon N., Bajt, V.), Ljubljana 2016, str. 51-62, http://www.mirovni-institut.si/wpcontent/ uploads/2016/03/Razor_wired_publikacija_web.pdf [15. 11. 2016]. 
Bešter, R., Model integracijske politike v odnosu do drugih modelov imigrantskih politik, Razprave in gradivo 53-54, 2007, str. 116-138.

Bhabha, H., Between Identities, Homi Bhabha interviewed by Paul Thompson, v: Migration \& Identity. Memory and Narrative Series (ur. Benmayor R., Skotnes A.), Oxford, New York 1994, str. 183-199.

Cohen, S., Folk Devils and Moral Panics. The creation of the Mods and Rockers, Oxon, New York 2011.

Drnovšek, M., Slovenians in the USA, Slovenia Weekly, Special Edition, junij 1999, str. 13.

Drnovšek, M., Emigration of Slovene Women: A Short Historical View, Dve domovini / Two Homelands 17, 2003, str. 29-46.

Gabaccia, D., Immigration and American Diversity. A Social and Cultural History, Oxford 2002.

Gosar, A., Obseg, vzročnost in karakteristike slovenskega izseljevanja v tujino, v: Izseljeništvo naroda i narodnosti Jugoslavije, Zagreb 1978, str. 144-159.

Josipovič, D., Preseljevanje Slovencev med jugoslovanskimi republikami in poselitveni vzorec po letu 1945, v: Priseljevanje in društveno delovanje Slovencev $v$ drugih delih jugoslovanskega prostora: zgodovinski oris in sedanjost (ur. Žitnik Serafin, J.), Ljubljana 2014, str. 119-135.

Josipovič, D., Slovenski otroci v migracijskih statistikah jugoslovanskega prostora: od migracij družin do "pionirskih migracij«, v: Slovensko izseljenstvo v luči otroške izkušnje (ur. Žitnik Serafin, J.), Ljubljana 2015, str. 145-156.

Kalc, A., in dr., Poti in usode, Selitvene izkušnje Slovencev z zahodne meje, Koper 2002.

Lukšič Hacin, M., Zgodbe in pričevanja. Slovenci na Švedskem, Ljubljana 2001.

Milharčič Hladnik, M., Ohranjanje etnične identitete in tradicije med slovenskimi izseljenci in njihovimi potomci v Združenih državah Amerike, Dve domovini / Two Homelands 19, 2004, str. 121-140.

Pajnik, M., Migration in the Mirror of the Mediatized Anti-politics, v: Razor-Wired. Reflections on Migrant Movements through Slovenia in 2015 (ur. Kogovšek Šalamon N., Bajt, V.), Ljubljana 2016, str. 63-72, http://www.mirovni-institut.si/wpcontent/ uploads/2016/03/Razor_wired_publikacija_web.pdf [15. 11.2016].

Repič, J., "Po sledovih korenin«: Transnacionalne migracije med Argentino in Evropo, Ljubljana 2006.

Sayad, A., The Suffering of the Immigrant, Cambridge 2004.

Sedmak, M., Kultura mešanosti: Družbeno in politično prepoznavanje socialne kategorije mešanih ljudi. Annales, Series Historia et Sociologia 21/2, 2011, str. 261-274. 
Smith, A. D., National Identity, London 1991.

Svoljšak, P., Begunstvo - nedokončana zgodba, v: Begunci, Slovenski begunci s soške fronte (ur. Beguš, I., Klavora, M.), Nova Gorica 2016, str. 8-17.

Štih, P., Migracije in oblikovanje kompleksnega kulturnega prostora med vzhodnimi Alpami in severnim Jadranom v srednjem veku, v: Migracije in slovenski prostor od antike do danes (ur. Štih, P., Balkovec, B.), Ljubljana 2010, str. 59-77.

Troha, N., Preselitve v Julijski krajini po drugi svetovni vojni. Prispevki za novejšo zgodovino 40/1, 2000, str. 255-268.

Troha, N., Odseljevanje in prebegi Slovencev z območja, ki je bilo z mirovno pogodbo z Italijo leta 1947 priključeno ljudski republiki Sloveniji, v: Migracije in slovenski prostor od antike do danes (ur. Štih, P., Balkovec, B.), Ljubljana 2010, str. 432-446.

Vižintin, M. A., Slovenski izseljenci in njihovi potomci v Nemčiji: dvajset let povezovanja slovenskih organizacij na posvetih, Dve domovini / Two Homelands 43, 2016, str. 157-172.

Vodopivec, P., Zgodovina Slovencev od Pohlinove slovnice do osamosvojitve, Ljubljana 2006.

Vrečer, N., Integracija kot človekova pravica, Prisilni priseljenci iz Bosne in Hercegovine v Sloveniji, Ljubljana 2007.

Wimmer, A., Glick Schiller, N., Methodological nationalism and beyond: nation-state building, migration and the social sciences, Global Networks 2/4, 2002, str. 301334. 


\section{Mirjam Milharčič Hladnik}

\section{Doživljanje »begunske krize« skozi intervencijo v javni diskurz: mi kot Drugi v zgodovinski perspektivi slovenskega izseljenstva in integracijskih praks}

Ključne besede: »begunska kriza«, konstrukcija Drugega, moralna panika, migracije, integracijske prakse

V Sloveniji je tako imenovana begunska kriza trajala od oktobra 2015 do marca 2016, ko se je balkanska pot zaprla. Javni diskurz je imel v tem obdobju značilnosti moralne panike, ki je izbruhnila ob napovedi madžarske vlade, da bo zaprla mejo s Srbijo in Hrvaško, kar je množice migrantov prisililo na pot do »Nemčije« preko Slovenije, in naenkrat potihnila ob zaprtju balkanske poti. Subjektivno doživljanje obdobja intenzivnega javnega interesa za migracije avtorica opiše preko svojih številnih intervencij v javni prostor. V njih je naslavljala dva sklopa strahov, tistega o valovih in nepreglednih množicah ljudi, ki prihajajo; in tistega o Drugih, ki jih ne bo mogoče integrirati na ravni Evrope in Slovenije. Obe intervenciji sta vsebovali zgodovinske podatke o slovenskem izseljenstvu in begunstvu, izkušnji, ki je potlačena in izrinjena iz kolektivnega spomina, nacionalne zgodovine in kulture ter iz šolskega sistema, ter podatke o integraciji migrantov in beguncev, ki v Sloveniji poteka zadnjih 25, v Evropski uniji pa zadnjih 50 let. Opozarjanje na lastne izkušnje migracij in begunstva $\mathrm{v}$ evropskem in slovenskem prostoru $\mathrm{v}$ javni diskurz vpelje razmislek o formiranju etnično, versko, jezikovno in kulturno raznolikih ter mešanih prebivalstev in družb, primeri integracijskih praks pa razmislek o tem, da so prav te prakse evropskim družbam omogočile, da so postale in ostale ekonomsko in socialno stabilne in varne. 
Mirjam Milharčič Hladnik

\section{Experiencing the "refugee crisis" through the Intervention into the Public Discourse: Us as the Others in the Historical Perspective of Slovenian Emigration and Integration Practices}

Keywords: "refugee crisis", moral panic, construction of the Other, migrations, integration practices

In Slovenia the so called refugee crisis lasted from October 2015 to March 2016, when the Balkan route was closed. The public discourse in this time had the characteristic of moral panic; it abruptly started when the Hungarian government closed the border with Serbia and Croatia, forcing masses of migrants to take the route to "Germany" via Slovenia, and as abruptly ended with the closure of the Balkan route. The subjective experience with the period of intense public interest in migration is described through many interventions by the author, who happened to be one of the many experts who were asked to comment on the "refugee crisis". Each intervention was intentionally the same, and addressed the same two clusters of public fears: first, the masses of migrants and refugees as a natural disaster that would destroy "everything", and, second, the impossibility of integration of masses of migrants into European and Slovenian societies. Each intervention insisted, first, on the forgotten historical facts about the intense migrations that have been a crucial part of the formations of Europe's ethnically, religiously, linguistically and culturally diverse and mixed populations and societies, and, second, on the forgotten facts about the recent successful integration practices that have evolved in Europe and Slovenia in the past fifty years and enabled them to become and remain economically and socially stable and safe. 